\title{
The Methodology of Formal Interpretation of Judicial Decisions by the International Court of Justice
}

\begin{abstract}
:
This article examines the International Court of Justice's methodology in cases where it interprets its own decisions under the procedure in Article 60 of the Statute. The Court is constrained by respect for the res judicata of the previous decision. When interpreting the decision the Court and its judges strive to find the intention behind a decision, and emphasise elements that include wording, context, and object and purpose. A comparison with how the Court interprets treaties, resolutions from the United Nations Security Council, and unilateral declarations by States show that the instruments have important different but that their interpretation nonetheless have some basic similarities. On this basis it may be possible to formulate general principles of interpretation in international law.
\end{abstract}


Contents:

1. Introduction 3

2. An overview of the relevant cases..............................................................................5

2.1 Contentious cases in the International Court of Justice ..............................5

2.2 Advisory opinions in the International Court of Justice ............................. 8

2.3 Cases in the Permanent Court of International Justice ............................... 9

3. The Court's methodology ........................................................................................10

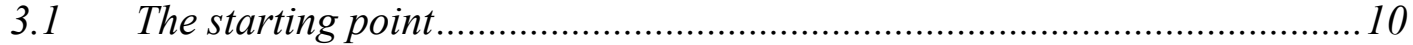

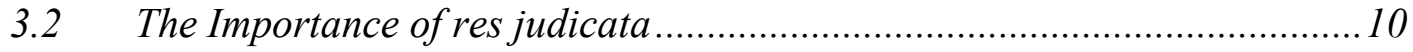

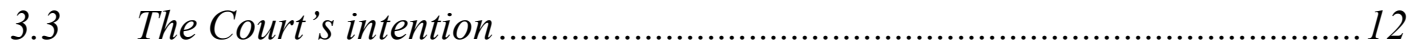

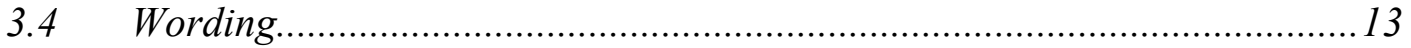

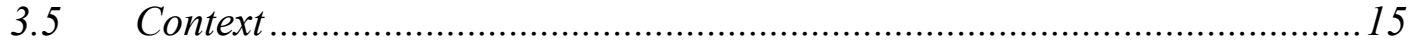

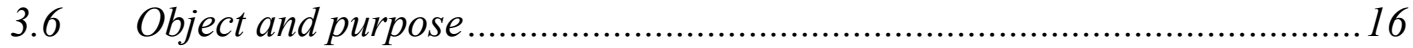

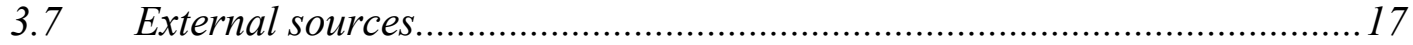

3.8 Submissions of the parties and circumstances of adoption ........................ 18

4. The Broader Context of the Court's methodology ...........................................19

4.1 Comparison with treaty interpretation ….................................................. 19

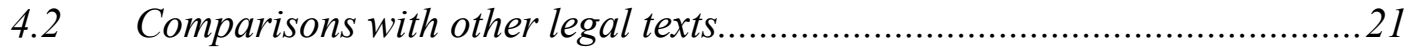

4.3 General principles of interpretation in international law .........................22

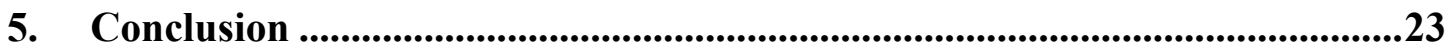




\section{Introduction}

There are numerous academic works focused on treaty interpretation. ${ }^{1}$ Much less attention has been given to the interpretation of other categories of texts in international law. ${ }^{2}$ Even so, all legal texts require interpretation. ${ }^{3}$ This includes judicial decisions. The law governing their interpretation is considerably less developed than the law of treaty interpretation. ${ }^{4}$ For example, many writers have covered the ICJ's formal procedure for interpretation judicial decisions, ${ }^{5}$ but they generally say nothing about the methodology that the Court applies when it interprets decisions.

Legal texts are interpreted by a variety of actors, including States, international organizations, courts and tribunals, and academics. ${ }^{6}$ The present article focuses on the interpretation of judicial decisions by one specific actor, the International Court of Justice (ICJ). The article also covers the practice of its predecessor, the Permanent Court of International Justice (PCIJ). One reason for focusing on the ICJ is that it is an authoritative and influential court, which makes it a good starting point for the analysis of most international legal issues. While ' $[t]$ here is [...] no systematic hierarchy among courts' ${ }^{7}$ the Court has been called 'the supreme public international law tribunal'. ${ }^{8}$ Other courts and tribunals tend to show 'substantial reliance' on its practice. ${ }^{9}$ The ICJ has a formal procedure for interpreting its previous judicial decisions, in the ICJ Statute Article ${ }^{10}$ 60, which gives a readily accessible set of relevant cases. Other courts and tribunals have similar procedures, in the European Convention on Human Rights ${ }^{11}$ Article 46(3), the American Convention on Human Rights ${ }^{12}$ Article 67, the ITLOS Statute ${ }^{13}$ Article 33, and the ICSID Convention ${ }^{14}$ Article 50. The European Court of Human Rights, the Inter-American Court of Human

${ }^{1}$ E.g. R. Gardiner, Treaty Interpretation (2nd edn, Oxford University Press 2017); U. Linderfalk, On the Interpretation of Treaties: The Modern International Law as Expressed in the 1969 Vienna Convention on the Law of Treaties (Spring 2007); R. Kolb, The Law of Treaties: An Introduction (Edward Elgar 2016).

${ }^{2}$ M. Wood, 'The Interpretation of Security Council Resolutions', (1998) 2 Max Planck Yearbook of United Nations Law 73, 73.

${ }^{3}$ O. Dörr and K. Schmalenbach, Vienna Convention on the Law of Treaties: A Commentary (Springer 2012), at 522; E. Papastavridis, 'Interpretation of Security Council Resolutions under Chapter VII in the Aftermath of the Iraqi Crisis' (2007) 56 International \& Comparative Law Quarterly 83, at 84.

${ }^{4}$ K. H. Kaikobad, Interpretation and Revision of International Boundary Decisions (Cambridge University Press 2007), 175.

${ }^{5}$ E.g. A. Zimmermann and T. Thienel, 'Article 60', in A. Zimmermann et. al., The Statute of the International Court of Justice: A Commentary (3nd edn, Oxford University Press 2019), 1617; S. Rosenne, Interpretation, Revision and Other Recourse from International Judgments and Awards (Brill 2007).

${ }^{6}$ Some of these and some others are mentioned by M. Herdegen, 'Interpretation in International Law' in R. Wolfrum (ed.), Max Planck Encyclopedia of Public International Law (last updated 2013), at para 2; M. Wood, 'The Interpretation of Security Council Resolutions, Revisited' (2017) 20 Max Planck Yearbook of United Nations Law 1, at 8.

${ }^{7}$ Eg J. Crawford, Chance, Order, Change: The Course of International Law (Brill 2014), 216.

${ }^{8}$ E.g. M. Mendelson, 'The International Court of Justice and the Sources of International Law' in V. Lowe and M. Fitzmaurice (eds.), Fifty Years of the International Court of Justice: Essays in Honour of Sir Robert Jennings (Cambridge University Press 1996) 63, at 83.

${ }^{9}$ E.g. International Law Commission, First report on formation and evidence of customary international law by Michael Wood, Special Rapporteur (A/CN.4/663) (2013), 28.

${ }^{10}$ Statute of the International Court of Justice, annex to the Charter of the United Nations, 26 June 1945, 1 UNTS XVI.

${ }^{11}$ Convention for the Protection of Human Rights and Fundamental Freedoms, 4 November 1950, 213 UNTS 221.

12 American Convention on Human Rights, 22 November 1969, 1144 UNTS 123.

${ }^{13}$ Statute of the International Tribunal for the Law of the Sea, Annex VI of the United Nations Convention on the Law of the Sea, 10 December 1982, 1833 UNTS 3.

${ }^{14}$ Convention on the settlement of investment disputes between States and nationals of other States, 18 March 1965, 575 UNTS 159. 
Rights, ICSID tribunals, and other arbitral tribunals have made formal interpretations of previous decisions, while the ITLOS has not. ${ }^{15}$ The practice of interpreting own decisions is thus not unique to the ICJ.

The ICJ may interpret judicial decisions in two different ways, in what may be called 'formal' and 'informal' interpretation. The former is governed by the ICJ Statute Article 60, which says that '[i]n the event of dispute as to the meaning or scope of the judgment, the Court shall construe it upon the request of any party'. ${ }^{16}$ This means that a party to a case before the Court may unilaterally institute a new case concerning the interpretation of the judgment in the previous case. ${ }^{17}$ An 'informal' interpretation of judicial decisions occurs when a decision by the Court refers to a previous decision, from itself or another court or tribunal, ${ }^{18}$ and it becomes necessary to clarify the meaning of the previous decision. This article focuses on formal interpretation. This type of interpretation is clearly identifiable and provides enough material for an article. It is possible that the Court has different approaches to the two types of interpretation. ${ }^{19}$ One difference is that formal interpretation is limited to the dispositif along with specific parts of the reasons of a decision, as explained in section 3.2 below, while informal interpretation is not subject to any such limitation. A formal and an informal interpretation of the same decision will therefore not necessarily relate to the same parts of the text. In any case, in practice it is difficult to imagine the Court reaching two disparate conclusions about the interpretation of the same opinion, simply because one interpretation was made under Article 60 while the other was not. Therefore, $t$ the current article could also shed some light on the 'informal' interpretation of judicial decisions, although any final conclusions on this point can only be drawn in future research.

This article is based on an analysis of seven cases from the ICJ and the PCIJ, which are presented in Section 2. As of December 2020 the ICJ had received six requests for interpretation of judgments in contentious cases under Article 60, which are discussed in section 2.2. Four of them produced interpretations that are referred to in the rest of this article. The article also refers to two interpretations of advisory opinions (section 2.3). The PCIJ received two requests for interpretation (Section 2.4), and one of them led to an interpretation that is referred to later in this article.

Section 3 extracts interpretive factors from the cases. The examination includes individual opinions, since in individual opinions the Court's "'workings" are set out in more detail', and they may therefore (better) 'reflect the Court's actual methods'. ${ }^{20}$ This makes them interesting, even though as sources of law, individual opinions are generally seen as less important than majority opinions. ${ }^{21}$

Section 4 places the Court's methodology in a broader descriptive and normative context, by comparing it with the interpretation of treaties, United Nations (UN) Security Council resolutions, and unilateral declarations by States, and raising the possibility of

${ }^{15}$ K.Oellers-Frahm, 'Judgments of International Courts and Tribunals, Interpretation of' in R. Wolfrum (ed.), Max Planck Encyclopedia of Public International Law (last updated 2019), at para 8-10.

16 There are additional details in the Rules of Court Article 98, but they are not significant here.

${ }^{17}$ K. Grzybowski, 'Interpretation of Decisions of International Tribunals' (1941) 35 American Journal of International Law 482, at 488-489 remarks that the right to institute such proceedings unilaterally is a divergence from previous practice, and at 495 that the Court would not have had such a power without the express provision in the Statute.

${ }^{18}$ Although the latter is rare in practice, as noted by e.g. M. D. Varella, Internationalization of Law: Globalization, International Law and Complexity (Springer 2014), 150.

${ }^{19}$ M. Bos, 'The Interpretation of International Judicial Decisions' (1981) 33 Revista Española de Derecho Internacional 11, at 34 argues in favour of making a distinction.

${ }^{20}$ J. Crawford, Brownlie's Principles of Public International Law (9th edn, Oxford University Press 2019), at 40.

${ }^{21}$ Eg M. Virally, 'The Sources of International Law', in M. Sørensen (ed.), Manual of Public International Law (St. Martin's Press 1968) 116, at 153-154. 
formulating general principles of interpretation in international law. The article also has this introduction (section 1) and a conclusion (section 5).

A caveat to the analysis is that the Court's interpretive approach is necessarily adapted to resolving the specific case and interpreting the specific judicial decision at issue. Different cases may therefore include or emphasise different factors. This may appear to present a challenge to any attempt to extract a unified approach from the Court's case law. This, however, is no different from the situation concerning treaties, where different treaties can have vastly different contents, parties, backgrounds, and characteristics. This has not prevented the formulation of general principles of treaty interpretation, as in the Vienna Convention on the Law of Treaties ${ }^{22}$ (VCLT) Article 31-33.

When deciding whether it can respond to a request for an interpretation, the Court requires two conditions to be fulfilled. These were outlined in Asylum: The first condition is that ' $[t]$ he real purpose of the request must be to obtain an interpretation of the judgment', and the second is that there is 'a dispute as to the meaning or scope of the judgment'. ${ }^{23}$ The Court in Temple labelled the first condition a matter of 'admissibility', and the second condition a matter of 'jurisdiction'. ${ }^{24}$ In previous cases it labelled the 'dispute' condition too a matter of admissibility. ${ }^{25}$ The latter approach is more appropriate, since, as Kulick argues, it 'is not a question of the correct forum', but 'whether ... the requirements are fulfilled to proceed to the merits'. ${ }^{26}$

\section{An overview of the relevant cases}

\subsection{Contentious cases in the International Court of Justice}

The six interpretation requests that the ICJ has received are Tunisia/Libya ${ }^{27}$ Temple $^{28}$ Asylum, ${ }^{29}$ Cameroon v. Nigeria,${ }^{30}$ Avena, ${ }^{31}$ and Pedra Branca/Pulau Batu Puteh. ${ }^{32}$

Tunisia/Libya was decided in 1985. Tunisia applied for the revision, interpretation, and correction of the Court's 1982 Judgment on the merits. ${ }^{33}$ The 1982 judgment concerned the delimitation of the two States' continental shelves. They asked the Court to outline

${ }^{22}$ Vienna Convention on the Law of Treaties, 23 May 1969, 1155 UNTS 331.

${ }^{23}$ Request for interpretation of the Judgment of November 20th, 1950, in the Asylum case, Judgment of November 27th, 1950, I.C.J. Reports 1950, p. 395, 402.

${ }^{24}$ Request for Interpretation of the Judgment of 15 June 1962 in the Case concerning the Temple of Preah Vihear (Cambodia v. Thailand) (Cambodia v. Thailand), Judgment, I.C.J. Reports 2013, p. 281, 295 and 302-303.

${ }^{25}$ E.g. Request for Interpretation of the Judgment of 31 March 2004 in the Case concerning Avena and Other Mexican Nationals (Mexico v. United States of America) (Mexico v. United States of America), Judgment, I.C.J. Reports 2009, p. 3, 10.

${ }^{26}$ A. Kulick, 'Article 60 ICJ Statute, Interpretation Proceedings, and the Competing Concepts of Res Judicata' (2015) 28 Leiden Journal of International Law 73, at 76. See also N Ridi, 'Precarious Finality? Reflections on Res Judicata and the Question of the Delimitation of the Continental Shelf Case' (2018) 31 Leiden Journal of International Law 383, 386.

${ }^{27}$ Application for Revision and Interpretation of the Judgment of 24 February 1982 in the Case concerning the Continental Shelf (Tunisia/Libyan Arab Jamahiriya) (Tunisia v. Libyan Arab Jamahiriya), Judgment, I.C.J. Reports 1985, p. 192.

${ }^{28}$ Temple (n 24).

${ }^{29}$ Asylum (n 23).

${ }^{30}$ Request for Interpretation of the Judgment of 11 June 1998 in the Case concerning the Land and Maritime Boundary between Cameroon and Nigeria (Cameroon v. Nigeria), Preliminary Objections (Nigeria $v$. Cameroon), Preliminary Objections (Nigeria v. Cameroon), Judgment, I.C.J. Reports 1999, p. 31.

${ }^{31}$ Avena (n 25).

${ }^{32}$ Request for Interpretation of the Judgment of 23 May 2008 in the case concerning Sovereignty over Pedra Branca/Pulau Batu Puteh, Middle Rocks and South Ledge (Malaysia/Singapore) (Malaysia v. Singapore).

${ }^{33}$ Continental Shelf (Tunisia/Libyan Arab Jamahiriya), Judgment, I.C.J. Reports 1982, p. 18. 
principles that they would apply for apportioning their overlapping continental shelf claims, which the Court did. ${ }^{34}$ In the 1985 case, the Court found Tunisia's request for revision of the 1982 Judgment inadmissible, ${ }^{35}$ and that the request for correction was 'without object'. ${ }^{36}$ Tunisia's request for an interpretation was admissible, and the Court accordingly interpreted the previous judgment. ${ }^{37}$ The request had two parts, focusing on the first and second sector of the delimitation line, respectively. The Court found the first part 'admissible' but 'founded upon a misreading'. The Court noted that there was 'nothing to be added' to the 1982 Judgment. ${ }^{38}$ The second part focused on the phrase 'the most westerly point', which the Court used about the Gulf of Gabes. ${ }^{39}$ The Court provided an interpretation of the 1982 Judgment, where it still left the main delimitation effort to the parties and their experts. ${ }^{40}$

Temple was decided in 2013. It concerned the interpretation of the Court's 1962 Judgment on the merits. ${ }^{41}$ The 1962 Judgment decided a border dispute between Cambodia and Thailand over an ancient temple. The Court ruled that the temple belonged to Cambodia and that Thailand had to withdraw its forces from Cambodian territory and restore objects taken from the site to Cambodia. ${ }^{42}$ Despite the Court's ruling, the subsequent decades saw several military clashes between two States, which still disagreed on how much of the area surrounding the temple that belonged to Cambodia. Cambodia initiated the 2013 case, arguing that the temple belonging to Cambodia and Thailand's obligation to withdraw were 'symbiotically linked'. ${ }^{43}$ Thus while the Court had ruled in 1962 that 'the Temple' belonged to Cambodia and that Thailand had to withdraw from 'its vicinity', Cambodia claimed that that vicinity too belonged to Cambodia. The Court found Cambodia's request admissible. ${ }^{44}$ It interpreted the previous decision and held 'that Cambodia had sovereignty over the whole territory of the promontory of Preah Vihear'. ${ }^{45}$

Asylum was decided in 1950. It concerned the interpretation of the Court's Judgment on the merits from the same year. ${ }^{46}$ The merits case was a dispute between Colombia and Peru over Colombia's grant of asylum to Peruvian national and the interpretation of the 1928 Havana Convention. ${ }^{47}$ The Court largely ruled in favour of Peru. Colombia requested an interpretation of the merits Judgment. The Court found that there was no 'dispute as to the meaning or scope of the judgment', as required by Article $60 .{ }^{48}$ It therefore declared the request 'inadmissible'. ${ }^{49}$ In order to reach this conclusion, however, the Court actually had to interpret the previous decision. The Court's reasoning in that regard is referred to in the later sections.

${ }^{34}$ Libya/Tunisia (n 33) 21-22 and 92-94

${ }^{35}$ Libya/Tunisia (n 27) 214

${ }^{36}$ Libya/Tunisia (n 27) 221

${ }^{37}$ Libya/Tunisia (n 27) 230.

${ }^{38}$ Libya/Tunisia (n 27) 220.

${ }^{39}$ Libya/Tunisia (n 27) 222.

${ }^{40}$ Libya/Tunisia (n 27) 210.

${ }^{41}$ Case concerning the Temple of Preah Vihear (Cambodia v. Thailand), Merits, Judgment of 1.5 June 1962: I.C.J. Reports 1962, p. 6.

${ }^{42}$ Temple (n 41) 36-37.

${ }^{43}$ Temple (n 24) 304.

${ }^{44}$ Temple (n 24) 304

${ }^{45}$ Temple (n 24) 318.

${ }^{46}$ Colombian-Peruvian asylum case, Judgment of November 20th 1950, I.C.J. Reports 1950, p. 266.

${ }^{47}$ Convention on Asylum, 20 February 1928, OAS Treaty Series No. 34.

48 Asylum (n 23) 403.

49 Asylum (n 23) 404. 
Cameroon v. Nigeria was decided in 1999. It concerned the interpretation of the Court's 1998 Judgment on preliminary objections. ${ }^{50}$ The Court decided the merits of the case only later, in a 2002 Judgment, where it delimited a part of the boundary between the two States and ordered both States to withdraw their respective forces from the other State's territory. ${ }^{51}$ Cameroon initiated the proceedings, and Nigeria contested the Court's jurisdiction over the case and the admissibility of Cameroon's clams, which is what the Court decided in its 1998 Judgment. ${ }^{52}$ The Court sided with Cameroon and found that it had jurisdiction and that the claims were admissible. ${ }^{53}$ Nigeria requested the interpretation of the 1998 Judgment, asking the Court to limit which factual circumstances that could be invoked in the proceedings on the merits, in three separate submissions. ${ }^{54}$ The Court rejected the first of these submissions because it had 'already clearly dealt with and rejected' it in the original judgment. ${ }^{55}$ The other two "endeavour to remove from the Court's consideration elements of law and fact which it has, in its Judgment of 11 June 1998, already authorized Cameroon to present, or which Cameroon has not yet put forward'. ${ }^{56}$ The Court therefore declared the request 'inadmissible'. ${ }^{57}$ It was not necessary to determine whether there was a 'dispute' under Article $60 .{ }^{58}$ However, in order to reach its conclusions, the Court had to interpret the original judgment. As with Asylum, the Court's reasoning in that regard is referred to in the later sections.

Avena was decided in 2009. It concerned the interpretation of the Court's 2004 Judgment on the merits. ${ }^{59}$ Mexico claimed that the US had violated the Vienna Convention on Consular Relations Article 36(1) and (2) by not granting Mexican nationals who had been sentenced to death in the US access to consular services, ${ }^{60}$ and the Court agreed. ${ }^{61}$ Mexico requested an interpretation of the 2004 Judgment, focusing on the section where the Court had specified 'the appropriate reparation'. ${ }^{62}$ This was for the US 'to provide, by means of its own choosing, review and reconsideration of the: convictions and sentences of the Mexican nationals'. ${ }^{63}$ In the 2009 case Mexico request the Court to interpret this to mean that no Mexican nationals should be executed before the 'review and reconsideration is completed'. ${ }^{64}$ The Court decided that Mexico's claim 'cannot give rise to the interpretation requested', since it did not concern 'matters which have been decided by the Court in its Judgment'. ${ }^{65}$ The Court was unsure about whether there was 'a dispute within the meaning of Article 60 of the Statute' ${ }^{66}$ In any case, the Court found that the question raised by Mexico 'is not decided in the Court's original Judgment and thus cannot be submitted to it for

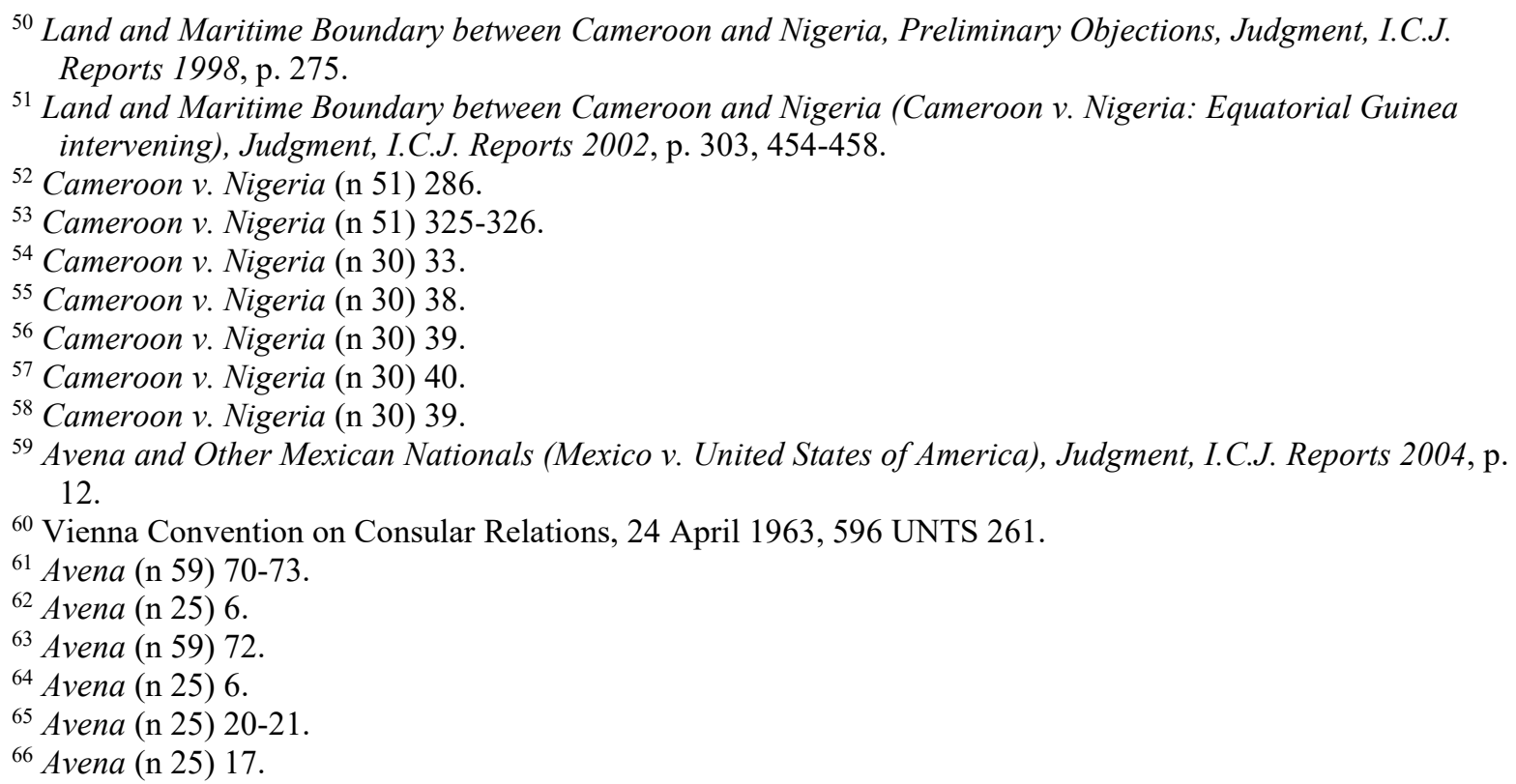


interpretation under Article 60 of the Statute' ${ }^{67}$ This finding necessitated some degree of interpretation of the original decision, but the Court's reasoning is brief and does not lend itself to the kind of analysis undertaken in this article. The decision is therefore not referred to in the rest of this article. Unlike in Asylum and Cameroon v. Nigeria, the Court did not declare outright that Mexico's request was 'inadmissible', but that was the practical effect of the ruling. ${ }^{68}$ The decision also dealt with various other requests by Mexico, which will not be discussed here. ${ }^{69}$

Pedra Branca/Pulau Batu Puteh concerned the interpretation of the Court's 2008 Judgment on the merits. ${ }^{70}$ The 2008 Judgment decided a territorial dispute between Singapore and Malaysia. The interpretation case was discontinued in 2018 without reaching the merits stage. The Court never engaged in an interpretation of the previous Judgment, and the case is therefore not referred to in the rest of this article.

\subsection{Advisory opinions in the International Court of Justice}

The Court has also been asked to be interpret an advisory opinion in two later advisory opinions: ${ }^{71}$ South-West Africa-Voting Procedure ${ }^{72}$ and Admissibility of hearings of petitioners by the Committee on South West Africa. ${ }^{73}$

The opinion in South-West Africa-Voting Procedure was given in 1955, while the one in Admissibility of hearings of petitioners by the Committee on South West Africa was given the year after, in 1956. The opinions were given in answer to two separate requests from the UN General Assembly concerning the interpretation of the Court's 1950 advisory opinion on the International Status of South West Africa. ${ }^{74}$

In the 1950 advisory opinion the United General Assembly posed three sets of questions about the legal relationship between South Africa, South West Africa (the precursor of Namibia) and the UN. ${ }^{75}$ The Court responded that South West Africa was still a South African mandate and that this gave South Africa various obligations, that the UN Charter chapter XIII applied, and that South Africa could not unilaterally change the status of the mandate. ${ }^{76}$

The 1955 advisory opinion was based on another request from the UN General Assembly, which cited the 1950 opinion and asked the Court to clarify what 'voting procedure' for the General Assembly that would be 'a correct interpretation of the [1950] advisory opinion'. ${ }^{77}$ The Court answered that 'questions relating to reports and petitions concerning the Territory of South-West Africa' are 'important questions' under the UN Charter Article 18(2). ${ }^{78}$

The 1956 advisory opinion was also prompted by a request from UN General Assembly. It asked whether it would be 'consistent with the [1950] advisory opinion [...] to grant oral hearings to petitioners on matters relating to the Territory of South West Africa'

${ }^{67}$ Avena (n 25) 17.

${ }^{68}$ Rosenne (n 5) 108.

${ }^{69}$ Avena (n 25) 21.

${ }^{70}$ Sovereignty over Pedra Branca/Pulau Batu Puteh, Middle Rocks and South Ledge (Malaysia/Singapore), Judgment, I.C.J. Reports 2008, p. 12.

${ }^{71}$ S. Rosenne, The Law and Practice of the International Court 1920-2005 (4th edn, Brill 2006), at 1001.

${ }^{72}$ South-West Africa-Voting Procedure, Advisory Opinion of June 7th, 1955, I.C.J. Reports 1955, p. 67.

${ }^{73}$ Admissibility of hearings of petitioners by the Committee on South West Africa, supra note 17.

${ }^{74}$ International status of South-West Africa, Advisory Opinion, I.C.J. Reports 1950, p. 128.

${ }^{75}$ International Status of South West Africa (n 74) 129-130.

${ }^{76}$ International Status of South West Africa (n 74) 143-144.

77 South-West Africa-Voting Procedure (n 72) 69.

${ }^{78}$ South-West Africa-Voting Procedure (n 72) 78. 
before the United Nation's Committee on South West Africa. ${ }^{79}$ The Court's response was that this 'would not be inconsistent with' the opinion. ${ }^{80}$

These interpretations took place outside the framework of Article 60, which does not cover advisory opinions. However, the opinions are similar to Article 60 cases, since they concerned the institution of new cases in order to interpret a previous opinion. They are therefore included in the present article. The Court's methodological framework in those cases was nonetheless different from cases about the interpretation of judgments, since the principle of res judicata did not apply, as explained in Section 3.2.

\subsection{Cases in the Permanent Court of International Justice}

The PCIJ Statute had a provision in Article 60 with the same wording as the ICJ Statute Article 60. The PCIJ dealt with two cases brought under that article: Treaty of Neuilly ${ }^{81}$ and Factory at Chorzów. ${ }^{82}$

Treaty of Neuilly was decided in 1925. It concerned the interpretation of the judgment on the merits of $1924 .{ }^{83}$ The 1924 case was based on a dispute between Greece and Bulgaria over the interpretation of the treaty that governed the post-World War One settlements between Bulgaria and neighbouring States. The Court ruled on which claims that were authorised under the treaty. ${ }^{84}$ Greece requested an interpretation of the 1924 Judgment. ${ }^{85}$ The PCIJ found that the request for an interpretation 'cannot be granted', because it would 'go beyond the limits of' the previous judgment. ${ }^{86}$ The PCIJ did not engage in any interpretation of the judgment, and the case is not referred to in the rest of this article.

Factory at Chorzów was decided in 1927. The request concerned two PCIJ judgments, delivered in 1926 and $1927 .{ }^{87}$ Both cases involved claims by Germany that Poland had violated international law when taking ownership of a factory in the city of Chorzów. ${ }^{88}$ In the 1926 Judgment the PCIJ largely sided with Germany, holding that various Polish actions were contrary to Poland's international obligations. ${ }^{89}$ In the 1927 Judgment the PCIJ ruled that it had jurisdiction over Germany's claims. ${ }^{90}$ This meant that the Court would decide that case too on the merits, which it did in $1928,{ }^{91}$ i.e. after it had interpreted the 1926 and 1927 judgments. The interpretation case was instituted by Germany. Germany claimed that Poland had misconstrued the PCIJ judgments when it annulled a contract transferring the disputed factory and instituted domestic court proceedings in Poland in order to achieve this. ${ }^{92}$ The PCIJ determined that the request actually concerned only the 1926 judgment. ${ }^{93}$ It

\footnotetext{
${ }^{79}$ Admissibility of hearings of petitioners by the Committee on South West Africa (n 73) 24.

${ }^{80}$ Admissibility of hearings of petitioners by the Committee on South West Africa (n 73) 32.

${ }^{81}$ Interpretation of Judgment No. 3, Judgment of 26 March 1925, Series A No.4.

${ }^{82}$ Interpretation of Judgments Nos. 7 and 8 (Factory at Chorzów), Judgment of 16 December 1927, Series A No. 13.

${ }^{83}$ Treaty of Neuilly, Article 179, Annex, Paragraph 4 (Interpretation), Judgment of 12 September 1924, Series A No. 3.

${ }^{84}$ Treaty of Neuilly (n 83) 9-10.

85 Treaty of Neuilly (n 81) 4-5.

${ }^{86}$ Treaty of Neuilly (n 81) 7.

${ }^{87}$ Certain German Interests in Polish Upper Silesia (Merits), Judgment of 25 May 1926, Series A No. 7; Factory at Chorzów (Jurisdiction), Judgment of 26 July 1927, Series A No. 9.

${ }^{88}$ Factory at Chorzów (n 87) 5; Certain German Interests in Polish Upper Silesia (n 87) 5.

${ }^{89}$ Certain German Interests in Polish Upper Silesia (n 87) 81-82.

${ }^{90}$ Factory at Chorzów (n 87) 33.

${ }^{91}$ Factory at Chorzów (Merits), Judgment of 13 September 1928, Series A No. 17.

92 Factory at Chorzów (n 82) 5.

${ }^{93}$ Factory at Chorzów (n 82) 16.
} 
went on to make an interpretation of that judgment, where it held that Poland's actions were 'null and void' and reaffirmed its original holding regarding ownership of the factory. ${ }^{94}$

\section{The Court's methodology}

\subsection{The starting point}

In Factory at Chorzów, the PCIJ laid down a starting point for the formal interpretation of judicial decisions: The PCIJ did "not consider itself as bound simply to reply "yes" or "no" to the propositions formulated in the submissions'. ${ }^{95}$ Instead, it would take 'an unhampered decision' ${ }^{96}$ This statement has been cited in later cases. ${ }^{97}$ This starting point gives the Court 'a certain degree of flexibility', ${ }^{98}$ and allows the Court to consider a variety of possibilities and relevant factors in its interpretive approach.

\subsection{The Importance of res judicata}

The Court has noted the importance of res judicata to its interpretations under Article 60. Res judicata means that 'a final adjudication by a court or arbitral tribunal is conclusive'. ${ }^{99}$ When the Court decides a case, 'that the matter is finally disposed of for good'. ${ }^{100}$ The decision is 'binding on the parties' and 'the matter cannot be subject to further litigation'. ${ }^{101}$ This contributes to legal certainty for the parties, ${ }^{102}$ which in turn contributes to the peaceful settlement of disputes. ${ }^{103}$ Preventing repeat trails is also economically efficient. ${ }^{104}$

The Court has called res judicata' 'a well-established and generally recognized principle of law'. ${ }^{105}$ It can be classified as one of the 'general principles of law' referred to in the ICJ Statute Article 38(1)(c). ${ }^{106}$ For the ICJ the principle is a combined effect of Article 59, 60, and 61. ${ }^{107}$ Article 59 says that an ICJ 'decision' is 'binding' between 'the parties'. Article 60 says that a 'judgment is final and without appeal', while Article 60 and 61 give procedures for the interpretation and revision of a decision. The Court itself has held that Article 60 'the language and structure of Article 60 reflect the primacy of the principle of res judicata'. ${ }^{108}$

${ }^{94}$ Factory at Chorzów (n 82) 22.

95 Factory at Chorzów (n 82) 15.

${ }^{96}$ Factory at Chorzów (n 82) 16.

${ }^{97}$ Libya/Tunisia (n 27) 223; Temple (n 24) 306.

98 Kulick (n 26) 78.

${ }^{99}$ W S Dodge, 'Res Judicata' in R. Wolfrum (ed.), Max Planck Encyclopedia of Public International Law (last updated 2013), at para 1.

${ }^{100}$ Barcelona Traction, Light and Power Company, Limited, Preliminary Objections, Judgment, I.C.J. Reports 1964, p. 6, 20.

${ }^{101}$ Ridi (n 26) 385.

102 Question of the Delimitation of the Continental Shelf between Nicaragua and Colombia beyond 200 Nautical Miles from the Nicaraguan Coast (Nicaragua v. Colombia), Preliminary Objections, Judgment, I.C.J. Reports 2016, p. 100, Joint dissenting opinion of Vice-President Yusuf, Judges Cançado Trindade, Xue, Gaja, Bhandari, Robinson and Judge ad hoc Brower 162.

${ }^{103}$ Kulick (n 26) 80.

${ }^{104}$ Ridi (n 26), 385.

${ }^{105}$ Effect of awards of compensation made by the U.N. Administrative Tribunal, Advisory Opinion of July 13th, I954, I.C.J. Reports 1954, p. 47, 53.

${ }^{106}$ Ridi (n 26) 386.

${ }^{107}$ C Brown, 'Article 59' in A. Zimmermann et. al., The Statute of the International Court of Justice: A Commentary (3nd edn, Oxford University Press 2019), 1561, 1272.

${ }^{108}$ Cameroon v. Nigeria (n 30) 36. 
According to Judge Anzilotti in Factory at Chorzów, the principle of res judicata has three elements: 'persona', 'petitum', and 'causa petendi', ${ }^{109}$ or parties, objects, and legal grounds. ${ }^{110}$ The ICJ will not accept a new case if it has already decided a case between the same parties over the same object and based on the same cause.

The principle also affects how the Court approaches the formal interpretation of its judicial decisions. In Temple, the Court referred to its previous jurisprudence claiming 'that the process of interpretation is premised upon the "primacy of the principle of res judicata" which "must be maintained". ${ }^{111}$ In practical terms this meant that "the Court must keep strictly within the limits of the original judgment and cannot question matters that were settled therein with binding force, nor can it provide answers to questions the Court did not decide in the original judgment'. ${ }^{112}$ In Asylum, it held that the 'object' of the request 'must be solely to obtain clarification of the meaning and the scope of what the Court has decided with binding force, and not to obtain an answer to questions not so decided'. ${ }^{113}$ Any other approach, the Court held, would 'nullify' the ICJ Statute Article 60. ${ }^{114}$ In Cameroon v. Nigeria the Court held that it 'would [...] be unable to entertain' one of Nigeria's submissions 'without calling into question the effect of the Judgment concerned as res judicata'. ${ }^{115}$

It is not necessarily clear which parts of an ICJ decision that are covered by the principle of res judicata. ${ }^{116}$ The parts of a decision that are covered by res judicata are the parts that can be interpreted under Article 60 but cannot be relitigated through a new dispute under Article 36. ${ }^{117}$ The ICJ Statute Article 60 simply gives 'the judgment' as the object of a formal interpretation. It is clear that the dispositif of a decision is res judicata. The uncertainty pertains to what parts of the decision's reasons that are also res judicata. In Temple, which is the Court's latest decision based on Article 60, it referred to previous cases where it held that reasons form part of the res judicata if they are 'inseparable' from the dispositif. ${ }^{118}$ However, the Court also referred to the PCIJ's decision in Factory at Chorzów, where it held that reasons form art of the res judicata if they were 'essential to the Court's decision'. ${ }^{119}$ The Court seemed to equate the two expressions, even though 'essential' is a less stringent requirement than 'inseparable'. ${ }^{120}$ This aspect of the decision was criticised in the Joint Declaration of Judges Owada, Bennouna and Gaja. ${ }^{121}$

There are good reasons for preferring a version of res judicata limited to dispositif and 'inseparable' reasons. That is in line with the Court's actual practice, and it limits the possibilities for relitigating cases through the interpretation procedure, without undermining the authority of the original decision. ${ }^{122}$

\footnotetext{
${ }^{109}$ Factory at Chorzów (n 82), Dissenting Opinion by M. Anzilotti 23.

${ }^{110}$ D Mejía-Lemos, 'The Principle of Res Judicata, Determination by "Necessary Implication," and the Settlement of Maritime Delimitation Disputes by the International Court of Justice' (2018) 5 Journal of Territorial and Maritime Studies 46, 52.

111 Temple (n 24) 303.

112 Temple (n 24) 306.

113 Asylum (n 23) 402.

114 Asylum (n 23) 402.

${ }^{115}$ Cameroon v. Nigeria (n30) 39.

${ }^{116}$ Kulick (n 26) 80-81.

117 Kulick (n 26) 80.

118 Temple (n 24) 296.

${ }^{119}$ Temple (n 24), referring to Factory at Chorzów (n 82) 20.

${ }^{120}$ Kulick (n 26) 81.

${ }^{121}$ Temple (n 24), Joint Declaration by Judges Owada, Bennouna and Gaja, 320.

122 Kulick (n 26) 88-89.
} 
Res judicata is a also concept in domestic legal systems, and it is found in both common law and civil law systems. ${ }^{123}$ While 'the res judicata doctrines of most Western societies are congruent', ${ }^{124}$ it may be possible to see differences between civil and common law jurisdictions. One difference is that res judicata is often codified in civil law jurisdictions. ${ }^{125}$ In common law system it is instead unwritten law, and often phrased as a matter of estoppel. ${ }^{126}$ In this sense the ICJ is closer to the civil law tradition, in that the res judicata is codified in the ICJ Statute, as noted in Section 3.2. Another difference is that common law systems tend to have a 'broader' form of res judicata than the 'narrower' civil law concept. ${ }^{127}$ In common law it can be more difficult to bring new cases, since 'the requirement of identity of cause' does not apply. ${ }^{128}$ In practice the Court applies a relatively narrow concept of res judicata where it can be said to have 'allowed' and even 'invited' States to relitigate cases. ${ }^{129}$ Even so, the principle of res judicata does set a limit to how far the Court is willing to go in interpreting its previous decisions.

The Court's advisory opinions have no res judicata and no dispositif. The opinions do have reasons and a final conclusion in the style of a dispositif, but they are without any res judicata effect. The Court's interpretation of a previous advisory opinion is therefore not limited to 'inseparable' motives in the way that an interpretation under Article 60 is.

\subsection{The Court's intention}

The Court and its judges have on multiple occasions emphasised that the Court's intention is significant when interpreting a judicial decision. ${ }^{130}$

An example is found in Libya/Tunisia, where the Court assessed the value of an argument in light of whether it could show what the Court 'intended'. ${ }^{131}$ Later in the same decision, the Court went on to explain what the Court 'meant' and 'did not mean'. ${ }^{132}$ In Temple, the Court concluded that it 'must have intended' for an obligation 'to withdraw military or police forces' to apply to a specific police detachment station near the disputed temple. ${ }^{133}$ In light of this, the Court drew a conclusion about how a phrase in the judgment 'ha[d] to be construed'. ${ }^{134}$ In other words, that the Court reached a conclusion about intention also meant that it had reached a conclusion about the disputed interpretation. Similar expressions from Temple focus on what the Court 'considered' or 'made clear'. ${ }^{135}$ The PCIJ's

${ }^{123}$ Ridi (n 26) 384.

${ }^{124}$ H Bagner, 'How to Avoid Conflicting Awards: The Lauder and CME Cases' (2004) 5 Journal of World Investment \& Trade 31, 33.

${ }^{125}$ C Söderlund, 'Lis Pendens, Res judicata and the Issue of Parallel Judicial Proceedings' (2005) 22(4) Journal of International Arbitration 301, 301]

${ }^{126}$ Söderlund (n 125) 301; D W Bowett, 'Estoppel before International Tribunals and its Relation to Acquiescence' (1957) 33 British Yearbook of International Law 176, 180.

${ }^{127}$ Y Sinay, 'Reconsidering Res Judicata: A Comparative Perspective' (2011) 21 Duke Journal of Comparative \& International Law 353, 358 and 384.

${ }^{128}$ J Pauwelyn, 'Going Global, Regional, or Both? Dispute Settlement in the Southern African Development Community (SADC) and Overlaps with the WTO and Other Jurisdictions' (2004) 13 Minnesota Journal of Global Trade 231, 292.

${ }^{129}$ B S Kantor and M E Z Achurra, 'The Principle of res judicata before the International Court of Justice: in the Midst of Comradeship and Divorce between International Tribunals' (2019) 10 Journal of International Dispute Settlement 288, 306.

${ }^{130}$ Bos (n 19) 44-45 agrees with that approach.

${ }^{131}$ Libya/Tunisia (n 27) 219.

${ }^{132}$ Libya/Tunisia (n 27) 225.

${ }^{133}$ Temple (n 24) 313.

${ }^{134}$ Temple (n 24) 313.

${ }^{135}$ Temple (n 24) 310 and 314 
decision in Factory at Chorzów drew a conclusion about 'the intention of the Court', as well as what 'the Court had in view'. ${ }^{136}$

In South-West Africa-Voting Procedure, the Court drew a conclusion about the previous opinion 'envisaged' and what one of its expressions 'was designed' for. ${ }^{137}$ Similarly, in Admissibility of hearings of petitioners by the Committee on South West Africa, the Court held that the previous opinion's 'intention' was 'evidenced' by its wording. ${ }^{138}$ Thus, intention seems to be a guide for formal interpretation under Article 60 as well as for the interpretation of advisory opinions.

Individual judges have also focused on intention when interpreting judicial decisions. They have discussed what previous judges "presumably understood'139 and "what the Court had in mind' 140 , and that the judges 'clearly acted on [an] understanding' ${ }^{141}$ in Article 60 interpretations. Along the same lines, when interpreting advisory opinions judges have focused on what 'idea' the opinion was 'based on', ${ }^{142}$ what the previous judges 'intended', ${ }^{143}$ and what 'intention' that can 'be imputed to the Court'. 144

Another question is whose intention that matters. This must be the intention of the Court as a whole, to the extent that such an intention existed. Intentions held only by a single judge are not relevant. This was underlined by Judge Schwebel in Libya/Tunisia, where he held that '[w]hatever may have been the understanding of one or more judges', what mattered was the intention of 'the Court as a whole'. ${ }^{145}$

An important reminder when seeking the intention behind an opinion is that the interpretation 'can in no way go beyond the limits of the Judgment, fixed in advance by the Parties themselves in their submissions', as the Court pointed out in Asylum. ${ }^{146}$

The examples listed above come from the interpretation of judgments as well as from the interpretation of advisory opinions. When it comes to the significance of discovering the Court's intention, there is no discernible difference between the two categories of cases.

While establishing intention seems to be significant, this can in most cases only be found by looking at relevant interpretative factors. This is well illustrated by the Temple case, where the Court held that while 'no one' factor was 'conclusive', they 'together' led to a conclusion about intention. ${ }^{147}$ The following subchapters present such interpretive factors.

\subsection{Wording}

Wording is an essential factor when the Court and its judges interpret a judicial decision.

The starting point when examining the terms used in a should be their 'ordinary and natural meaning', as emphasised by the Court in South-West Africa-Voting Procedure. ${ }^{148}$

\footnotetext{
${ }^{136}$ Factory at Chorzów (n 82) 19 and 20.

137 South-West Africa-Voting Procedure (n 72) 73 and 77.

${ }^{138}$ Admissibility of hearings of petitioners by the Committee on South West Africa (n 73) 31.

${ }^{139}$ Libya/Tunisia (n 27), Separate opinion of Judge Bastid, at 251.

${ }^{140}$ Libya/Tunisia (n 27), Separate opinion of Judge Oda 241.

${ }^{141}$ Libya/Tunisia (n 27), Separate opinion of Judge Schwebel, at 246.

${ }^{142}$ Admissibility of hearings of petitioners by the Committee on South West Africa (n 73), Declaration by Judge Winiarski, at 33.

143 South-West Africa-Voting Procedure (n 72), Separate Opinion of Judge Basdevant, at 81; Admissibility of hearings of petitioners by the Committee on South West Africa (n 73), Dissenting Opinion of Vice-President Badawi and Judges Basdevant, Hsu Mo, Armand-Ugon and Moreno Quintana, at 67.

${ }^{144}$ Admissibility of hearings of petitioners by the Committee on South West Africa (n 73), Separate Opinion of Sir Hersch Lauterpacht, at 39.

${ }^{145}$ Libya/Tunisia (n 27), Separate opinion of Judge Schwebel, at 246.

${ }^{146}$ Asylum (n 23) 403.

147 Temple (n 24) 315

148 South-West Africa-Voting Procedure (n 72) 72.
} 
Judge Lauterpacht in the same case similarly focused on the '[a]ccepted usage' of terms, ${ }^{149}$ while the majority in Admissibility of hearings of petitioners by the Committee on South West Africa emphasised 'general purport and meaning'. ${ }^{150}$ These cases concerned the interpretation of advisory opinions, but the same point should hold true for interpretation under Article 60.

In some cases it may be necessary to go deeper than the current usage of a term, as Judge Cançado Trindade did in Temple, when he looked at ' $[\mathrm{t}]$ he etymological origins of' a word. ${ }^{151}$ In Temple the Court's majority held that 'a description was implicit'. ${ }^{152}$ The wording of an opinion is more than what is expressly said.

Some interpretations can apparently be decided by wording alone. In Libya, the Court concluded that in the previous decision, "the Court, by referring to "the most westerly point on the shoreline (low-water mark) of the Gulf of Gabes" meant exactly what it said'. ${ }^{153}$ In Temple the Court found a 'meaning' to be 'clear'. ${ }^{154}$ In other cases the wording of the previous decision presents two clear alternatives. In Cameroon v. Nigeria, Judge Weeramantry pondered two alternative interpretations of the phrase 'additional facts'. ${ }^{155} \mathrm{In}$ South-West Africa-Voting Procedure, Judge Basdevant (interpreting an advisory opinion) wondered how to interpret "the word "procedure", and contrasted 'a general and a vague sense' of the word. ${ }^{156}$

Other cases are more complex. Judge Lauterpacht, interpreting an advisory opinion in South-West Africa-Voting Procedure, warned about the "unreliability of reliance on the supposed ordinary and natural meaning of words'. ${ }^{157}$ He found that a disputed term had 'no ordinary and natural meaning [...] in the abstract'. ${ }^{158}$

The Court has emphasised what a previous decision 'expressly stated', ${ }^{159}$ as has Judge Bastid. ${ }^{160}$ The absence of a certain wording can also be significant. In Libya, the Court noted that the in the previous decision, 'the Court was careful not to indicate' a certain wording. ${ }^{161}$ The absence of a certain wording was also noted later in the same case, in that 'that the operative part of the Judgment did not mention the latitude in question'. ${ }^{162}$ The same thing can be seen in the interpretation of advisory opinions: In the Dissenting Opinion of VicePresident Badawi and Judges Basdevant, Hsu Mo, Armand-Ugon and Moreno Quintana in Admissibility of hearings of petitioners by the Committee on South West Africa, the judges underlined that " $[\mathrm{t}]$ he words are "which applied"-not "which might have been applied" or "which was applicable". ${ }^{163}$

When the Court and its judges interpret judicial decisions, they often 'stress the importance' of specific 'words', as Judge Bastid put it in Libya. ${ }^{164}$ This focus on individual words is a way of giving wording a prominent role in the interpretive process. Examples

149 South-West Africa-Voting Procedure (n 72), Separate Opinion of Judge Lauterpacht, at 95.

${ }^{150}$ Admissibility of hearings of petitioners by the Committee on South West Africa (n 73) 27.

${ }^{151}$ Temple (n 24), Separate Opinion of Judge Cançado Trindade, at 328.

152 Temple (n 24) 316.

${ }^{153}$ Libya/Tunisia (n 27) 225.

${ }^{154}$ Temple (n 24) 310.

${ }^{155}$ Cameroon v. Nigeria (n 30), Dissenting Opinion of Vice-President Weeramantry, at 44.

${ }^{156}$ South-West Africa-Voting Procedure (n 72), Separate Opinion of Judge Basdevant, at 81.

157 South-West Africa-Voting Procedure (n 72), Separate Opinion of Judge Lauterpacht, at 93.

158 Ibid 95.

${ }^{159}$ Libya/Tunisia (n 27) 226; Factory at Chorzów (n 82) 18.

${ }^{160}$ Libya/Tunisia (n 27), Separate opinion of Judge Bastid, at 251.

${ }^{161}$ Libya/Tunisia (n 27) 224.

162 Ibid 226.

${ }^{163}$ Admissibility of hearings of petitioners by the Committee on South West Africa (n 73), Dissenting Opinion of Vice-President Badawi and Judges Basdevant, Hsu Mo, Armand-Ugon and Moreno Quintana, at 66.

${ }^{164}$ Libya/Tunisia (n 27), Separate opinion of Judge Bastid, at 252. 
include the Court's majority opinion in the same case, where it was said to be 'significant, first that the mention of that latitude was qualified by the word "approximately". ${ }^{165} \mathrm{In}$ Temple, the Court quoted the previous decision, with an 'emphasis added' to certain words and phrases. ${ }^{166}$ That reveals a careful reading of the previous opinion, with great attention to its exact wording. In Factory at Chorzów, the PCIJ emphasised 'the use of the present tense' in the original judgment. ${ }^{167}$ An example from an individual opinion is the stress put on the word 'aligned' in Judge Bastid's opinion Libya. ${ }^{168}$ In an example from the interpretation of advisory opinions, Judge Lauterpacht's opinion in South-West Africa-Voting Procedure identified what he called 'crucial passages' in the original opinion, which he duly quoted and interpreted. ${ }^{169}$

\subsection{Context}

Context is another interpretive factor that the Court and its judges apply.

As noted in Section 3.2, in under Article 60 the Court may interpret both a judicial decision's dispositif and some of its reasons. One approach to this is to consider the reasons as part of the dispositif's context.

The Court's opinion in Temple thus invoked a 'map' in an annex to previous opinion that 'played a central role in the reasoning of the Court'. ${ }^{170}$ On the other hand, in Temple the Court did not find that 'the headnote' of the previous decision could '[assist] in resolving the questions of interpretation' that were before it. ${ }^{171}$ This was because 'the headnote is not one of the elements of the Judgment'. ${ }^{172}$ This displays the limits of the use of reasons as 'context' for the dispositif. The headnote was not an 'essential' or 'inseparable' part of the reasons, it was not part the judgment at all.

It is also possible to use the different parts of the dispositif as contexts for each other. That is what the Court did in Temple, where it held that 'the three operative paragraphs have to be considered as a whole', since 'the task of ascertaining their meaning and scope cannot be reduced to an exercise of construing individual words or phrases in isolation'. ${ }^{173}$ The original judgment had three paragraphs in the dispositif. Only two were subject to dispute in the interpretation proceedings. The Court found that the remaining paragraph was 'nonetheless relevant to the extent that it sheds light on the meaning and scope of the rest of the operative part'. ${ }^{174}$

The interpretation of advisory opinions is not limited to 'essential' or 'inseparable' parts of the reasons. Under these freer limits, an interesting example of the use of context is found in the Dissenting Opinion of Vice-President Badawi and Judges Basdevant, Hsu Mo, Armand-Ugon and Moreno Quintana in Admissibility of hearings of petitioners by the Committee on South West Africa. The judges made a thorough interpretation of what the Court held in the reasons of the original opinion, and they found that their understanding was '[i]n harmony with' what 'the Opinion states, in its operative clause'. ${ }^{175}$

165 Libya/Tunisia (n 27) 226.

166 Temple (n 24) 316.

${ }^{167}$ Factory at Chorzów (n 82) 19.

${ }^{168}$ Libya/Tunisia (n 27), Separate opinion of Judge Bastid, at 251.

${ }^{169}$ South-West Africa-Voting Procedure (n 72), Separate Opinion of Judge Lauterpacht, at 93.

${ }^{170}$ Temple (n 24) 308.

${ }^{171}$ Temple (n 24) 307.

172 Temple (n 24) 307.

${ }^{173}$ Temple (n 24) 310.

${ }^{174}$ Temple (n 24) 316.

${ }^{175}$ Admissibility of hearings of petitioners by the Committee on South West Africa (n 73), Dissenting Opinion of Vice-President Badawi and Judges Basdevant, Hsu Mo, Armand-Ugon and Moreno Quintana, at 63. 
In addition to dispositifs and reasons being interpreted in light of each other, both may be interpreted in light of other types of context.

A clear example is found in Factory at Chorzów, where the PCIJ interpreted a specific 'passage' from the original judgment, it and found that its 'very context' was 'calculated to establish' a certain legal result. ${ }^{176}$

Another example is found in Libya, where the Court noted that the 'figures used the Judgment' had to 'be read in its context', in order to establish what the Court 'intended'. ${ }^{177}$ These figures were part of the reasons of the original judgment, which the Court in the interpretation proceedings presumably found to be 'essential' to or 'inseparable' from the dispositif. Interpreting the figures in their 'context', which includes other parts of the reasons, may be seen as a way for the Court to draw on parts of the reasons that not necessarily themselves 'essential' or 'inseparable'. This is not an evasion of the limits described in section 3.2 above, but it does show that those limits are in practice less absolute than they may appear.

There are similar examples in the interpretation of advisory opinions. Judge Lauterpacht in South-West Africa-Voting Procedure argued that it was 'of importance [...] to bear in mind the relation between [...] two passages'. ${ }^{178}$ Judge Lauterpacht also read a specific 'passage [...] not in isolation but in the general context of the Opinion' ${ }^{179}$ In Admissibility of hearings of petitioners by the Committee on South West Africa, Judge Lauterpacht took this a step further, and relied on 'the principle that a legal text must be interpreted as a whole'. ${ }^{180}$ In the same case, the Dissenting Opinion of Vice-President Badawi and Judges Basdevant, Hsu Mo, Armand-Ugon and Moreno Quintana simply used 'the remainder of the sentence' that included the disputed term as context. ${ }^{181}$

\subsection{Object and purpose}

The object and purpose of the previous decision is another factor that has played a role in the Court's practice. ${ }^{182}$

A clear example is found in the Dissenting Opinion of Vice-President Badawi and Judges Basdevant, Hsu Mo, Armand-Ugon and Moreno Quintana in Admissibility of hearings of petitioners by the Committee on South West Africa, where the judges identified ' $[\mathrm{t}] \mathrm{he}$ purpose of the Opinion'. ${ }^{183}$ In the same case, the Court as a whole identified a 'paramount purpose' of the original opinion, and thought it 'not permissible, in the absence of express words to the contrary' to interpret the decision in a way that would be contrary to that purpose. ${ }^{184}$ At the same time, the safeguard about 'words to the contrary' means that wording can override the object and purpose, which, in turn, shows the great weight the Court gives to wording.

In other cases the wording and object and purpose are in harmony, as in the Dissenting Opinion of Vice-President Badawi and Judges Basdevant, Hsu Mo, Armand-Ugon

\footnotetext{
${ }^{176}$ Factory at Chorzów (n 82) 20.

${ }^{177}$ Libya/Tunisia (n 27) 219.

${ }^{178}$ South-West Africa-Voting Procedure (n 72), Separate Opinion of Judge Lauterpacht, at 96.

${ }^{179}$ South-West Africa-Voting Procedure (n 72), Separate Opinion of Judge Lauterpacht, at 112.

${ }^{180}$ Admissibility of hearings of petitioners by the Committee on South West Africa (n 73), Separate Opinion of Sir Hersch Lauterpacht, at 46.

${ }^{181}$ Admissibility of hearings of petitioners by the Committee on South West Africa (n 73), Dissenting Opinion of Vice-President Badawi and Judges Basdevant, Hsu Mo, Armand-Ugon and Moreno Quintana, at 66.

${ }^{182}$ Kaikobad (n 4) 178-225 mentions '[t] he principle of effectiveness', which is similar, according to e.g. Gardiner (n 1) 221.

${ }^{183}$ Admissibility of hearings of petitioners by the Committee on South West Africa (n 73), Dissenting Opinion of Vice-President Badawi and Judges Basdevant, Hsu Mo, Armand-Ugon and Moreno Quintana, at 64.

${ }^{184}$ Admissibility of hearings of petitioners by the Committee on South West Africa (n 73) 28.
} 
and Moreno Quintana in Admissibility of hearings of petitioners by the Committee on South West Africa, where ' $[\mathrm{t}]$ he spirit of the Opinion thus fully confirms what is expressed by its letter'. 185

The PCIJ in Factory at Chorzów rejected an argument that would be 'depriving' a conclusion in 'the judgment of its logical and necessary foundation'. ${ }^{186}$ In Libya, the Court rejected a 'wholly unrealistic' interpretation. ${ }^{187}$

Judges have also held that that every part of an opinion must have some purpose. This is illustrated by the Dissenting Opinion of Vice-President Badawi and Judges Basdevant, Hsu Mo, Armand-Ugon and Moreno Quintana in Admissibility of hearings of petitioners by the Committee on South West Africa, where 'the second part of the sentence in question would then be pointless' under a given interpretation, which was a strong argument against adopting that interpretation. ${ }^{188}$ Judge Lauterpacht's opinion in the same case is also relevant, since he '[could] not accept any such interpretation of the Advisory Opinion of 1950 which may go a long way towards reducing its principal qualifying provision to a mere form of words'. ${ }^{189}$ Judge Lauterpacht also emphasised the need to read the previous opinion 'as a whole', in order to infer its true object and purpose. ${ }^{190}$ Judge Lauterpacht interpreted the opinion relatively freely, choosing an interpretation that was 'not fundamentally inconsistent with' the wording of the opinion, in order 'give effect to its essential purpose'. ${ }^{191}$ Judge Schwebel in Libya held that certain 'terms' in the previous opinion risked being 'inexplicable' unless the interpretation he favoured was adopted. ${ }^{192}$

An interesting pattern in the examples discussed above, is that most of them come from the two interpretations of advisory opinions rather than from the more numerous interpretations of judgments. Section 3.3 showed that when interpreting either judgments or advisory opinions, judges try to find the Court's intention. The process of ascertaining this intention may be somewhat different in practice, however. It is possible that the Court and its judges give less weight to object and purpose when interpreting judgments, and that such interpretations instead remain more loyal to wording. A plausible explanation for such a pattern is that when interpreting judgments, the Court is constrained by res judicata, as explained in section 3.2.

\subsection{External sources}

In South-West Africa-Voting Procedure, Judge Basdevant interpreted the original opinion in light of provisions in the UN Charter, specifically Articles 18, 20 to 22 and 27. ${ }^{193}$ This is an example of a judge interpreting a judicial decision in light of a rule of international law. ${ }^{194} \mathrm{In}$

${ }^{185}$ Admissibility of hearings of petitioners by the Committee on South West Africa (n 73), Dissenting Opinion of Vice-President Badawi and Judges Basdevant, Hsu Mo, Armand-Ugon and Moreno Quintana, at 65.

${ }^{186}$ Factory at Chorzów (n 82) 19.

${ }^{187}$ Libya/Tunisia (n 27) 226.

${ }^{188}$ Admissibility of hearings of petitioners by the Committee on South West Africa (n 73), Dissenting Opinion of Vice-President Badawi and Judges Basdevant, Hsu Mo, Armand-Ugon and Moreno Quintana, at 67.

${ }^{189}$ Admissibility of hearings of petitioners by the Committee on South West Africa (n 73), Separate Opinion of Sir Hersch Lauterpacht, at 40.

${ }^{190}$ Admissibility of hearings of petitioners by the Committee on South West Africa (n 73), Separate Opinion of Sir Hersch Lauterpacht, at 45.

191 Admissibility of hearings of petitioners by the Committee on South West Africa (n 73), Separate Opinion of Sir Hersch Lauterpacht, at 51.

${ }^{192}$ Libya/Tunisia (n 27), Separate opinion of Judge Schwebel, at 246.

${ }^{193}$ South-West Africa-Voting Procedure (n 72), Separate Opinion of Judge Basdevant, at 81.

${ }^{194}$ Kaikobad (n 4) 226-227 argues that there is 'a rule enabling tribunals to interpret an award or decision on the general rebuttable presumption that the terms of the previous decisions were consistent with general principles of law'. Bos (n 19) 44-45 agrees. 
South-West Africa-Voting Procedure, the Court read the original opinion in light of a related resolution by General Assembly. ${ }^{195}$

Both of these examples are found in the interpretation of advisory opinion. This too may be because the Court's interpretive room for manoeuvre is larger in such cases than when interpreting judgment, since it is not constrained by res judicata.

\subsection{Submissions of the parties and circumstances of adoption}

The Court has on multiple occasions interpreted a previous decision in light of the submissions that the parties made before the Court in the previous proceedings.

In particular, the Court has pointed out that certain arguments were not raised in submissions. The Court made this point twice in Asylum, the second time inferring that ' $[\mathrm{t}] \mathrm{he}$ Judgment in no way decided' the point, 'nor could it do so'. ${ }^{196}$ The same inference was made in Libya, where the Court noted the lack of 'large-scale charts or maps of the Gulf' in the parties' submissions. ${ }^{197}$ In Temple, the Court found 'no evidence' or 'suggestion' in the previous submissions that could support a claim made by Cambodia in the interpretation proceedings. ${ }^{198}$

Not all the Court's inferences from previous submissions have focused on what was absent from those submissions. In Cameroon v. Nigeria, the Court 'would initially recall what were Cameroon's submissions' when it began an interpretation. ${ }^{199}$ In Temple, the Court referred to what 'counsel for Cambodia observed'. ${ }^{200}$ Later on the Court found, more tentatively, 'certain indications in the record' regarding Cambodia's view of the disputed temple. ${ }^{201}$ In Temple the Court also looked at 'the evidence that was before the Court' in the original case. ${ }^{202}$

This means that the principle of res judicata, as described in section 3.2, has not prevented the Court from drawing upon the submissions of the parties. This is sensible, since the submissions define the petitum, and thus shape what must be considered res judicata in the final judgment. The Court in Temple thus referred to ' $[\mathrm{t}]$ he principle of non ultra petita' as 'one reason why the claims contained in the final submissions of the Parties in the original case are of relevance in interpreting the 1962 Judgment' ${ }^{203}$ It backed this up with reference to its previous jurisprudence. This can be inferred from the point that the Court made later in the same opinion, that ' $[t]$ he scope of the operative part of a judgment of the Court is necessarily bound up with the scope of the dispute before the Court'. ${ }^{204}$

When drawn upon, the submissions of the parties do not become the objects of the interpretation as such, but they do become part of the interpretive process. This is similar to the function of context, which was described in section 3.5 above, and represents another way in which the limits on the Court's approach are in practice less absolute than they may appear.

In one of its interpretations of an advisory opinion, the Court took into account the circumstances of the adoption of the previous opinion. In South-West Africa-Voting

\footnotetext{
195 South-West Africa-Voting Procedure (n 72) 76.

${ }^{196}$ Asylum (n 23) 402-403.

${ }^{197}$ Libya/Tunisia (n 27) 226.

198 Temple (n 24) 315.

${ }^{199}$ Cameroon v. Nigeria (n 30) 37.

${ }^{200}$ Temple (n 24) 310.

${ }^{201}$ Temple (n 24) 314.

${ }^{202}$ Temple (n 24) 312.

${ }^{203}$ Temple (n 24) 307.

${ }^{204}$ Temple (n 24) 316.
} 
Procedure, the Court found that its interpretation of certain 'words' was 'confirmed by an examination of the circumstances which led to their use'. ${ }^{205}$

\section{The Broader Context of the Court's methodology}

\subsection{Comparison with treaty interpretation}

Discussions of interpretation in international law often start with a reference to the VCLT Article 31-33. These articles are a binding statement on interpretive methodology in international law. They reflect customary international law, which means that they are relevant to States that are not parties to the VCLT. ${ }^{206}$ Even so, the VCLT only applies to treaties (as defined in its Article 2(1)(a)).

The findings outlined above might make it tempting to draw similarities between the formal interpretation of judicial decisions. ${ }^{207}$ On the most basic level, both judicial decisions and treaties are written texts whose interpretation is governed by international law.

Additionally, most of the factors identified in section 3 are also reflected in the VCLT. This includes wording ('ordinary meaning'), 'context', and 'object purpose', as well as 'relevant rules of international law' and 'the circumstances of [the treaty's] conclusion'. The ICJ has held that treaties must be interpreted 'in accordance with the intentions of its authors as reflected by the text of the treaty and the other relevant factors', ${ }^{208}$ which sounds similar to the focus on the Court's intention in the formal interpretation of judicial decisions.

The International Law Commission's 1966 Draft Articles on the Law of Treaties with commentaries attempted to draw a distinction between how much 'relative weight' different jurists 'give to' three factors: ${ }^{209}$

(a) The text of the treaty as the authentic expression of the intentions of the parties;

(b) The intentions of the parties as a subjective element distinct from the text; and

(c) The declared or apparent objects and purposes of the treaty.

Comparing this with the Court's formal interpretation of judgments, the Court's preference seems to be for option (a). Intention is significant, but it is always bound up with the actual text of the previous judgment. This is a necessary consequence of the central purpose in the formal interpretation of judicial decisions, which is to respect the res judicata of the original decision, as discussed in Section 3.2. This purpose constitutes a difference between the interpretation of treaties and the formal interpretation of judicial decisions. The Court must take care not to make what would in practice be a new decision of the case, or to make an interpretation that would invite even further litigation of what is supposed to be a settled case.

When interpreting treaties, a central purpose is to give effect to the intention of the parties. The parties have consented to a text, and this consent is the limit of the interpreter's room for manoeuvre. Treaty interpretation can therefore be said to be less constrained than the formal interpretation of judicial decisions. ${ }^{210}$ This makes the two operations fundamentally different, even though they may look superficially similar.

\footnotetext{
205 South-West Africa-Voting Procedure (n 72) 73.

${ }^{206}$ E.g. Oil Platforms (Islamic Republic of Iran v. United States of America), Preliminary Objection, Judgment, I.C.J. Reports 1996, p. 803, at 812.

${ }^{207}$ A. Orakhelashvili, The Interpretation of Acts and Rules in Public International Law (Oxford University Press 2008), 495. Kaikobad (n 4) 175 notes a 'close parallel' and 'a clear analogy, albeit limited' between the two types of interpretation.

${ }^{208}$ Dispute regarding Navigational and Related Rights (Costa Rica v. Nicaragua), Judgment, I.C.J. Reports 2009 , p. 213 , at 237.

${ }^{209}$ International Law Commission, Draft Articles on the Law of Treaties with commentaries (1966) 218.

${ }^{210}$ Herdegen (n 6) para 60.
} 
Differences between the two instruments are also found in their drafting process. When the Court drafts a judicial decision, an important aim is to settle a dispute between two parties. The Court's 'function' of the ICJ is 'to decide [...] disputes', as stated in the ICJ Statute Article 38(1). However, the Court also plays a role in developing international law. ${ }^{211}$ When deciding cases, the Court's judges are aware that many States will model their behaviour on its pronouncements. More broadly the Court is concerned with the maintenance of international peace and public order. ${ }^{212}$ This can be seen in, among other things, the UN Charter 2(3) and 92, which say that UN members 'shall settle their international disputes by peaceful means' and that the Court is 'the principal judicial organ of the United Nations'. ${ }^{213}$ Treaties are drafted for the purpose of regulating some subject matter between their parties. They do not have the conflict resolving function of judicial decisions. Some treaties are 'lawcreating', ${ }^{214}$ but those that are not will have contribute to the development of international law in the way that ICJ decisions do. Another nuance to this is that the ICJ's formal interpretation of judicial decisions is limited to dispositif and 'inseparable' or 'essential' reasons. Dispositifs generally focus on resolving the specific dispute that is before the Court, while statements that contribute to the development of international law are more often found in other parts of a decision. This means that the Court's formal interpretation of judicial decisions will often focus on parts of a decision that are less significant to the broader development of international law. In short, the aims behind the drafting of treaties and ICJ decisions overlap in part, depending on the specific case, but they are not the same.

Treaties are produced by consent between the parties that are bound by them. By contrast, a judicial decision is made unilaterally by the Court. Treaties are generally created through 'negotiation and compromise' between the parties. ${ }^{215}$ The drafting of a judicial decision may require some negotiation and compromise between the judges, but the parties who will be bound by the decision do not participate in its drafting beyond presenting arguments through their counsel. The Court therefore uses the judicial decision as a tool for explaining the result to the parties. Treaties do not have the explanatory function of judicial decisions. They can, in fact, be deliberately used to mask lingering differences between the parties.

These differences and similarities between treaties and judicial decisions influence affect how they are drafted and should also affect how they are interpreted. The nuances found in the comparison above caution against flatly assuming that treaty interpretation and the formal interpretation of judicial decisions are subject to the same interpretive framework.

The Court itself has commented on the question of parallels between the two types of interpretation. In Temple, it held that '[a] judgment of the Court cannot be equated to a treaty', and that the VCLT 'Article 31, paragraph 3 (b)' was not applicable. ${ }^{216}$ Similarly, the arbitral tribunal in the Argentina-Chile Frontier Case held that 'is it proper to apply stricter rules to the interpretation of an Award determined by an Arbitrator than to a treaty'. ${ }^{217}$ In other words, the interpretation of judicial decisions and the interpretation of treaties were not governed by exactly the same rules. This is because an arbitral award is 'determined by an Arbitrator', while a treaty 'results from negotiation between two or more Parties' ${ }^{218}$ While a

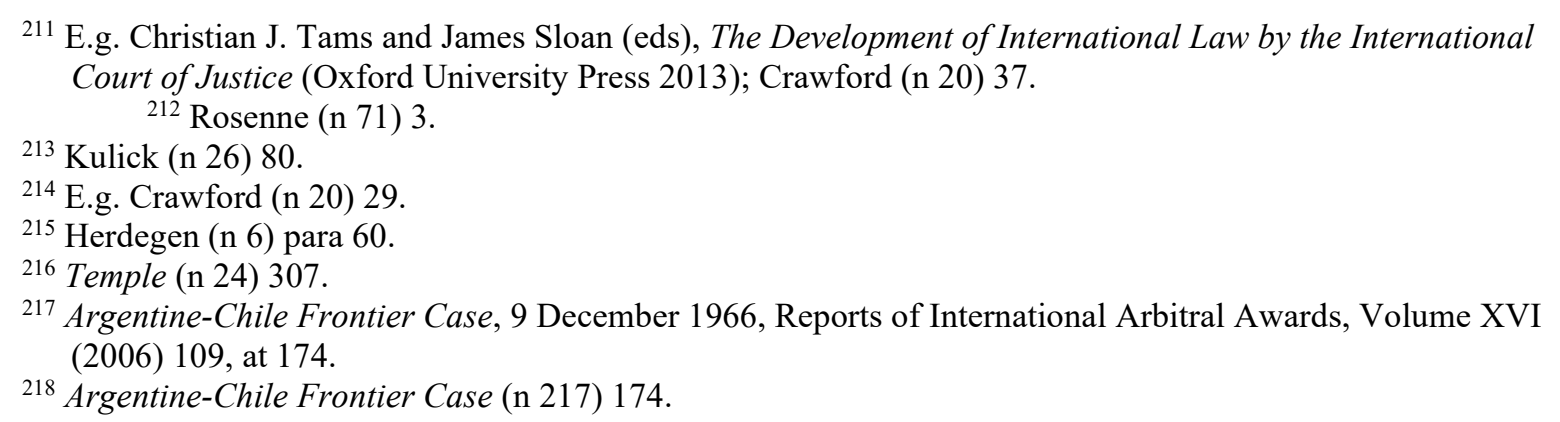


treaty can be interpreted in light 'preparatory documents' and 'subsequent actions of the Parties', the interpretation of an award should be confined to the 'Award itself' ${ }^{219}$ By contrast, Judge Lauterpacht argued in his Separate Opinion in Admissibility of hearings of petitioners by the Committee on South West Africa that while the principles of treaty interpretation are not 'directly germane' to the interpretation of judicial decisions, they do offer 'useful instruction [...] by analogy'. ${ }^{220}$ It is important to note that this pronouncement was made in the interpretation of an advisory opinion, where the issue of res judicata does not apply, as explained in Section 3.2.

\subsection{Comparisons with other legal texts}

The Court has also commented on how to interpret other legal texts.

One category of such texts is resolutions by the UN Security Council. These can be binding on all UN member States, under the UN Charter Article 25. They are adopted by the fifteen members of the Security Council, and the five permanent members may veto any resolution (Article 27). In its Kosovo advisory opinion, the Court held that the VCLT 'may provide guidance' to the interpretation of such resolutions, but that 'differences between the two categories of text 'require that other factors be taken into account'. ${ }^{221}$ In particular, the Court drew attention to the fact that resolutions, unlike treaties, can 'be binding on [...] States without their specific consent, irrespective of whether they played any part in their formulation'. ${ }^{22}$ States have consented to the UN Charter, from which the Security Council derives its legal authority. They have, as a rule, not consented to each specific resolution. That is similar to judicial decisions in the ICJ, where cases can only be brought with the consent of the parties, but where the content of the decisions is outside the States' control. Compared with treaties, the intentions of the Security Council member States should have less weight when interpreting resolution than the intentions of the States parties have when interpreting treaties.

In Kosovo the Court also noted that resolutions 'are drafted through a very different process than that used for the conclusion of a treaty'. ${ }^{223}$ This means that differences in drafting may lead to different approaches to interpretation, as argued for treaties and judicial decisions in Section 4.1 above. The Court identified some relevant factors in the interpretation of Security Council resolutions: 'statements by representatives of members of the Security Council made at the time of their adoption', 'other resolutions of the Security Council on the same issue', and 'subsequent practice of relevant United Nations organs and of States affected by those given resolutions'. These seem similar to the factors in the VCLT Article 31-32, including 'preparatory work', 'relevant rules of international law', and 'subsequent practice'.

Unilateral declarations is another category of texts where the Court has acknowledged that fundamental differences affect interpretive methodology. States can bind themselves through unilateral declarations. This can be the effect of a treaty, such as the ICJ Statute Article 36(4), under which States can unilaterally declare that they will be bound by the

${ }^{219}$ Argentine-Chile Frontier Case (n 217) 174.

${ }^{220}$ Admissibility of hearings of petitioners by the Committee on South West Africa (n 73), Separate Opinion of Sir Hersch Lauterpacht, at 47.

${ }^{221}$ Accordance with International Law of the Unilateral Declaration of Independence in Respect of Kosovo, Advisory Opinion, I.C.J. Reports 2010, p. 403, at 442. See also Prosecutor v. Slobodan Milosevic, Decision on Preliminary Motions, 8 Nov 2001, at para 47: '[t]he Statute of the International Tribunal is interpreted as a treaty'; Responsibilities and obligations of States with respect to activities in the Area, Advisory Opinion, 1 February 2011, ITLOS Reports 2011, p. 10, at 29: when interpreting certain 'Regulations adopted by the Authority', the VCLT 'may, by analogy, provide guidance'.

${ }^{222}$ Kosovo (n 221) 442.

${ }^{223}$ Kosovo (n 221) 442. 
Court's jurisdiction. Unilateral declarations can also be binding without basis in a specific treaty. Several cases before the PCIJ and the ICJ have turned on such declarations. ${ }^{224}$

Unilateral declarations may have to be interpreted. In the Nuclear Tests cases the Court found that 'a restrictive interpretation is called for' when interpreting unilateral declarations. ${ }^{225}$ This presumably refers to an approach is that is more restrictive than the approach used in treaty interpretation. In Cameroon v. Nigeria the Court accordingly held 'that the régime for depositing and transmitting declarations of acceptance of compulsory jurisdiction laid down in Article 36, paragraph 4, of the Statute of the Court is distinct from the régime envisaged for treaties by the Vienna Convention'. ${ }^{226}$ The Court cited this statement in Fisheries Jurisdiction, and added that the VCLT 'may only apply analogously to the extent compatible with the sui generis character of the [declarations]'. ${ }^{27}$ Treaties and unilateral declarations are different in that the latter do not involve the consent of any other state. It may therefore be appropriate to give a high priority to the intention of the declaring State. Unilateral declarations and judicial decisions share the trait of not being not drafted through negotiation or compromise between equal parties.

\subsection{General principles of interpretation in international law}

The above comparisons show that the Court recognises a need to interpret different instruments differently. This conclusion can be placed in a broader context, by asking whether all legal texts in international law may be interpreted according to the same general principles of interpretation. Orakhelashvili favours that view. ${ }^{228}$ So does Lauterpacht, albeit writing before the adoption of the VCLT, in that that treaty interpretation embodies 'rules of common sense and good faith' that 'are relevant to all legal instruments'. ${ }^{229}$ Wood does not see the same parallels, 'beyond the basic injunction that interpretation must be carried out in good faith'. 230

The interpretation of different instruments in international law, be it treaties, judicial decisions, UN Security Council resolution, or unilateral declarations, are subject to two competing impulses. One the hand these instruments are different in their purposes, drafting, and functions, as argued in sections 4.1 and 4.2 above. It seems unhelpful to force them all into a single interpretive mould for the sake of conceptual harmony. On the other hand, the principles in the VCLT are so open-ended and reasonable that they seem appropriate for most legal texts. The different factors that the VCLT identifies may apply differently to different instruments and with different weight, but it is hard to imagine a category legal text that should not be interpreted according to the basic factors of wording, context, purpose, and so on.

${ }^{224}$ E.g. Legal Status of Eastern Greenland, Judgment of 5 April 1933, P.C.I.J. Series A/B No. 53; Frontier Dispute, Judgment, I.C.J. Reports 1986, p. 554.

${ }^{225}$ Nuclear Tests (Australia v. France), Judgment, I.C.J. Reports 1974, p. 253, at 267; Nuclear Tests (New Zealand v. France), Judgment, I.C.J. Reports 1974, p. 457, at 473.

${ }^{226}$ Cameroon v. Nigeria (n 50) 293.

${ }^{227}$ Fisheries Jurisdiction (Spain v. Canada), Jurisdiction of the Court, Judgment, I.C.J. Reports 1998, p. 432, at 453. See also Maritime Delimitation and Territorial Questions between Qatar and Bahrain, Jurisdiction and Admissibility, Judgment, I.C.J. Reports 1995, p. 6, at 18, which applied 'customary international law, reflected in Article 31 of the 1969 Vienna Convention on the Law of Treaties' when interpreting 'minutes' that according to one party to the case contained a unilateral declaration.

${ }_{228}$ Orakhelashvili (n 207) 463 and 584.

${ }^{229}$ Admissibility of hearings of petitioners by the Committee on South West Africa (n 73), Separate Opinion of Sir Hersch Lauterpacht, at 47-48. Similarly J.-M. Sorel and V. Bore-Eveno, 'Article 31 (1969)', in O. Corten and P. Klein (eds.), The Vienna Conventions on the Law of Treaties: A Commentary (Oxford University Press 2011) 804, at 805.

${ }^{230}$ Wood (n 6) 7. 
In short, the question of whether there are general principles of interpretation in international law is one where nuanced analysis is more suitable than an either-or answer.

\section{Conclusion}

This article has presented a systematic analysis of the approach used by the ICJ and its judges when interpreting their own judicial decisions under the procedure in the ICJ Statute Article 60 .

The Court has identified a 'starting point' where it considers itself relatively free in its interpretive approach. The Court is nonetheless constrained by the principle of res judicata, since it is interpreting a final, binding decision that is not meant to be relitigated. An important goal of the Court and its judges when interpreting judicial decisions seems to be to ascertain the intention, of the Court as a whole, behind the decision. Significant factors are the wording of the opinion, and its context and object and purpose. Other factors include external sources, the submissions of the parties, and the circumstances of the adoption of the opinion. There is a difference in principle between the interpretation of judgments and of advisory opinions. Whether this translates into different approaches by the Court and its judges in practice is difficulty to say for certain, but it seems like they feel freer to draw on factors such as object and purpose and external sources when interpreting advisory opinions.

The formal interpretation of judicial decisions shares both differences and similarities with the interpretation of other international legal instruments that the Court has interpreted, such as treaties, UN Security Council resolution, and unilateral declarations. UN Security Council resolution and judicial decisions are both binding on States that do not partake in their drafting, while treaties and unilateral are only binding the specific States that consent to or give them. These instruments are also drafted differently and for different purposes. It is nonetheless possible to speak about general principles of interpretation in international law, based on the VCLT, but the specific approach when interpreting each type of instrument will in most cases have some differences.

Future research may shed light on how other courts and tribunals approach the formal interpretation of judicial decisions, which may provide a greater empirical basis for conclusions about the existence of general principles of interpretation in international law. Comprehensive examinations of the ICJ's and other courts and tribunals' practice when interpreting other legal instruments could also make for interesting comparisons when combined with the results presented in this article. 